\title{
Gestaltegewing van geloof - Aspekte van outentieke geloofskommunikasie
}

\author{
Author: \\ Elsabé Kloppers \\ Affiliation: \\ ${ }^{1}$ Department of Practical \\ Theology, University of \\ South Africa, South Africa \\ Correspondence to: \\ Elsabé Kloppers \\ Email: \\ kloppec@unisa.ac.za \\ Postal address: \\ PO Box 392, UNISA 0003 , \\ South Africa \\ Dates: \\ Received: 29 Aug. 2011 \\ Accepted: 05 Sept. 2011 \\ Published: 04 Nov. 2011 \\ How to cite this article: \\ Kloppers, E., 2011, \\ 'Gestaltegewing van geloof \\ - Aspekte van outentieke \\ geloofskommunikasie', \\ HTS Teologiese Studies/ \\ Theological Studies 67(3), \\ Art. \#1166, 6 pages. http:// \\ dx.doi.org/10.4102/hts. \\ v67i3.1166
}

C) 2011. The Authors. Licensee: AOSIS OpenJournals. This work is licensed under the Creative Commons Attribution License.
Faith embodied - Aspects of the authentic communication of the faith

In this article a theological theory for the communication of the faith is addressed from the basic metaphor of the Church as the body of Christ, within the fields of church publications, visual communication, the worship service and church music. It is argued that words (spoken, published or sung), music, art, gestures, visual images, silences and open spaces, are all communicative actions performing on a symbolic or metaphorical level to express and communicate the faith. Through these communicative actions the corporate identity of the community of faith is shaped and the body of Christ is built up. It is argued that in the church the act of communicating should adhere to certain theological principles to be true to its essence and aim: to communicate the faith faithfully and trustworthy.

\section{Inleiding}

Gedurende professor Theuns Dreyer se termyne as voorsitter van die Kommissie van die Algemene Kerkvergadering het Wian Kloppers en ek op verskillende terreine nóú met hom saamgewerk om die kommunikasie van geloof op 'n breë vlak in die kerk te bevorder. Ek het gemeen dit is dus gepas om vir 'n Festschrift navorsing ten opsigte van die kommunikatiewe handelinge van geloof op ons onderskeie terreine, naamlik kerkpublikasies, visuele verkondiging, die erediens en kerkmusiek saam te vat met betrekking tot die neerslag en betekenis vir die Nederduitsch Hervormde Kerk. Op al hierdie terreine afsonderlik word kommunikatiewe handelings verrig met die oog op die oordrag van die evangelie, maar omdat kommunikasie deur metafore en simbole plaasvind, bestaan daar ook 'n noue verband tussen die wyses van kommunikasie op hierdie terreine. Deur meerdere simboliese handelinge word aan die geloof gestalte gegee - word die geloof dus sigbaar en hoorbaar gemaak. Die kommunikatiewe handelinge van geloof is egter ook daarop gerig om die geloofsgemeenskap sigbare gestalte te gee, om (geloofs)identiteit te vorm, en om die liggaam van Christus op te bou met die oog op die uitdra van die evangelie na ' $n$ wêreld 'daar buite'.

Die vraag is dus hoe lyk ons onderlinge kommunikasie en hoe behoort dit te lyk? Watter middele word gebruik? Wat is die gees waarin gehandel word? Hoe word die kerk in die wêreld sigbaar en hoorbaar gemaak? Wat is die beeld wat die kerk uitstraal en wat die wêreld waarneem? Wat is die 'korporatiewe identiteit' van die kerk? Hoe lyk die kommunikatiewe handelinge van geloof en hoe moet dit in werklikheid lyk? Watter veranderings en verbeterings kan in die praktyk van kommunikasie aangebring word? Die vraag wat aangespreek moet word, is hoe daar in die onderskeie handelingsvelde kommunikatiewe handelinge gestimuleer kan word wat die geloof kan oordra en versterk; wat onderlinge koinonia sal bevorder; wat sal meewerk om die liggaam van Christus op te bou; en wat sal bydra om die korporatiewe identiteit van die kerk meer na die beeld van Christus te vorm, sodat die kerk vanuit hierdie identiteit as liggaam van Christus, 'n positiewe invloed na die wêreld kan uitstraal.

\section{'n Teologiese kommunikasieteorie: Die liggaam van Christus as grondmetafoor vir die kerk se beeld en identiteit}

Kommunikatiewe handelinge in diens van die evangelie is op outentieke ontmoeting gerig die ontmoeting tussen God en mense, die ontmoeting tussen gelowiges onderling en tussen gelowiges en 'die mense daar buite'. Deur die ontmoeting met God kom mense tot geloofsverstaan en so tot ware selfverstaan - en daaruit tot verstaan van ander en van die werklikheid. Die kommunikatiewe handelinge werk dus mee om die geloofsgemeenskap tot stand te bring en die onderlinge koinonia te bevorder. Deur die ontmoeting met God en met mekaar word die identiteit van die gelowige en die identiteit van die geloofsgemeenskap gevorm. Die gemeenskap van gelowiges kom nie voort uit ' $n$ algemeen menslike poging om tot onderlinge begrip te kom en handelinge te koördineer nie, maar is geleë in die verbondenheid aan Christus:

De kerk als gemeenschap vindt haar oorsprong en bestemming niet in de gemeenschap die ze zelf vormt, maar in de participatie van ieder van de leden aan Christus. De deelname aan Christus vormt 
het fundament en het doel van de gemeenschappelijkheid en verbondenheid van de kerk. De kerk als gemeenschap bestaat bij gratie van de gemeenschap die Christus haar gratuïteit aanbiedt en sticht.

(Van der Ven 1993:236)

Die metafoor van die kerk as die liggaam van Christus kan as die grondmetafoor dien vir die spreke oor die liggaamlike, oftewel korporatiewe identiteit van die kerk. Die begrip korporatiewe identiteit word oorgebruik en oorbelaai, maar dit is juis relevant binne die kerk waar die handelende liggaam van Christus ter sprake is. Die korporatiewe identiteit van ' $n$ kerk is die sigbare beeld wat ' $n$ kerk deur haar lewe en werk ín die wêreld na buite kommunikeer. Dit is die sigbare gestalte van die kerk wat so geloofwaardig moet wees dat ' $n$ samelewing buite die kerk die gestalte ook kan waarneem en kan glo wat gekommunikeer word.

As liggaam van Christus het die kerk dus 'n besondere verantwoordelikheid en opdrag. Watter beeld vertoon die kerk as liggaam van Christus egter in die wêreld? Is die lewe van die kerk ' $n$ uitnodiging om aan die liggaam van Christus deel te hê? Gaan daar inderdaad lewegewende krag en inspirerende hoop van die kerk na die wêreld toe uit? Wat is die identiteit van die kerk wat sigbaar gemaak word in die wêreld? Skerp kritiek word dikwels teen die kerk ingebring van buite, maar ook van binne die kerk. Verwyte word gehoor dat die kerk nie die Christelike liefde wat verkondig word, weerspieël nie; dat die kerk nie in staat is om ondersteuning, sekuriteit en rigting te bied nie; dat die kerk afsydig is teenoor mense in nood; dat die kerk nie die mense se vrae en leefwêreld verstaan nie; dat die kerk voeling verloor het met die probleme in die samelewing, en dat teoloë uit verhewe torings praat asof hulle oor die finale kennis oor God beskik - asof hulle trouens oor God self beskik!

Die beeld van die kerk, die sigbare gestalte van die kerk, dít wat die buitewêreld sien en ervaar, word deur die wyse van onderlinge kommunikasie binne die kerk, sowel as die kommunikasie van die kerk na buite, bepaal. Die kerk se manier van kommunikeer, optrede, 'liggaamstaal' en sigbare verkondiging, is van deurslaggewende belang vir effektiewe en geloofwaardige optrede na binne en na buite. Egte en effektiewe kommunikasie is noodsaaklik vir die voortbestaan van die kerk. Om relevant te bly, moet daar op elke vlak erns gemaak word met die wyses van kommunikasie na binne en na buite. Die kerk se styl van kommunikasie en die kommunikasiemoontlikhede in die kerk behoort dus voortdurend ondersoek, getoets en aangepas te word. ' $n$ Teologiese teorie as onderbou en grondslag vir kommunikasie in die kerk is noodsaaklik, sodat van daaruit vernuwende moontlikhede in die praktyk geïmplementeer en uitgebou kan word.

Bäumler (1984) ontwikkel 'n teologiese kommunikasieteorie in aansluiting by Habermas (1982) se teorie vir kommunikatiewe handelinge en argumenteer dat ten einde geloofwaardig te wees, kommunikatiewe handelinge in die gees van die geskenkte vryheid van Christus moet plaasvind. Dit moet dus ooreenstem met die gees van liefde van Jesus Christus, naamlik dié van openheid, vryheid, gelykwaardigheid, toegeneëntheid en uitnodigende optrede - optrede wat vry is van heerssug en wat gerig is op deelname en solidariteit. Volgens Bäumler is dit nie verre ideale nie, maar beginsels wat deurgaans in die geskiedenis van die Christendom as noodwendige kriteria gestel is: 'Der Leitgedanke der Freiheit realisiert sich in bestimmten Spielregeln der Kommunikation: Offenheit, Herrschaftsfreiheit, Partizipation, Solidarität' (Bäumler 1984:44).

'n Nie-outoritêre, heersersvrye, oop en akkommoderende vorm van kommunikasie wat gerig is op deelname en solidariteit moet nagestreef word. Wanneer so 'n niestrategiese, nie-manipulerende kommunikasiestyl eerlik nagetreef word, moet gevra word na die magsverhoudings wat ' $n$ rol speel in besluitnemingsprosesse. Zerfaß (1994:126) toon dat vanuit ' $n$ handelingsteoretiese perspektief die volgende vrae onder andere gevra moet word: Wie definieer die situasie? Wie bepaal prioriteite? Is daar 'n bereidheid om mag af te staan? Hy wys op verskillende situasies waar mag deelname belemmer en bepleit ' $n$ alternatiewe omgang met mag, asook 'n afskeid van 'machtförmigem Denken'. God stel self die voorbeeld: In Christus kommunikeer God met mense deur 'n 'afdaal na menslike vlak' om op 'gelyke vlak' met mense te kommunikeer. Eers waar gelowiges mekaar in vrye, gelyke, dialogiese en simmetriese kommunikasie ontmoet, kan die potensiaal tot ' $n$ ware gemeenskap in die geloof ten volle verwesenlik word.

In 'n studiestuk met die oog op 'n verruimde en vernuwende kommunikasiepraktyk in die Nederduitsch Hervormde Kerk (Kloppers 2004:164-165) word Christelike kommunikasie in aansluiting by bogenoemde uitgangspunte onder meer aangedui as nie-instrumenteel, dialogies, simmetries, eerlik, eg en deursigtig:

- Nie-instrumenteel beteken kommunikasie ter wille van vertroue, verhouding, liefde en sorg. Dit is nie kommunikasie as instrument om iets te bereik, of mense te gebruik nie. Die gespreksgenoot word as gelyke in ' $n$ dialoog beskou en nie as ondergeskikte instrument nie. Die vraag kan gevra word of die sender of mededeler ernstig is om die boodskap aan die ontvanger of vertolker tuis te bring - met ander woorde of die 'sender' in werklike verstaan, in eksistensiële ontmoeting, geïnteresseerd is (vgl. Dingemans 1991:42).

- Dialogies beteken 'n gelyke verkeer na weerskante as senders en ontvangers van 'n boodskap. Die een oorheers nie as sender en die ander is nie ondergeskik as ontvanger nie. Geslaagde kommunikasie vind eers plaas waar die ontvanger van die boodskap op die boodskap gereageer het en bewys gelewer is dat die boodskap ontvang en verstaan is. Volgens Habermas (1984:10) is daar eerder na beide kante van subjekte sprake. Elke spraakhandeling beskik oor ' $n$ interaktiewe en artikulerende dimensie wat 'n verhouding tussen kommunikerende subjekte vestig en die motiewe en bedoelinge van sodanige kommunikerende subjekte vergestalt. Subjekte moet konformeer aan die intersubjektiwiteit van dialoog ten einde wedersydse 
begrip en verstaan te verwesenlik. Kognitiewe aansprake kan uiteindelik slegs getoets en besleg word deur intersubjektiewe gesprekvoering. Dikwels word die gesindheid egter ervaar dat die kommunikasie sonder meer 'afgehandel' is. Terugvoer word dan as lastig of negatief beleef, veral wanneer dit daarop dui dat die hoorders dalk nie die boodskap reg 'vertolk' het nie, of indien dit blyk dat hul behoeftes ánders is as waarop staatgemaak is. Die huidige kommunikasiepraktyk in die kerk blyk veral boodskapgeörienteerd in plaas van dialooggeörienteerd te wees:

It seems quite obvious that much Christian communication practice is based on a one-way concept, which is partly due to a lack of information about the audience. This has left us with message-oriented theories of communication, where emphasis is placed on the design of the message rather than on the intended listener. The audience is viewed as a target, and "ideas and feelings are prepacked in a mental and physical syringe and then forced under pressure in a straight line into the receiver."

(Søgaard 1993:41)

- Simmetries gee uitdrukking aan gelykwaardigheid in die kommunikasieproses. Habermas (1982 II:40-45) beskryf dit as heersersorye kommunikasie. Die kerk word gekritiseer dat daar dikwels van outoritêre en eenrigtingkommunikasie gebruik gemaak word. ... Dit is waarskynlik 'n rede waarom die kerk dikwels as te formeel, hoogdrawend, neerbuigend en ver van die lidmate af, beleef word. Daar moet veel meer gedoen word om die lidmate aktiewe deelnemers aan die gesprek te maak en nie slegs 'ontvangers' van 'n bepaalde boodskap nie.

- Eerlike, egte kommunikasie: Die nieverbale vorm van kommunikasie bevorder die egtheid van kommunikasie of die teendeel daarvan. Die parateks, oftewel die geheelboodskap wat bereik word deur die geslaagde verbinding tussen die verbale en nieverbale (metateks), is uiters belangrik. Die verbale en nieverbale in die kommunikasieproses moet saamval en moet dus konsekwent wees. Die interteks word grootliks deur hierdie saamval bepaal en beïnvloed alle pogings tot kommunikasie.

- Deursigtig: Wedersyds behoort niks weggesteek te word nie. Subtekste wat iets anders kommunikeer as wat verbaal oorgedra word, lei tot wantroue. 'n Bewussyn vir die nieverbale, die regte 'lyftaal', behoort doelbewus op alle vlakke bevorder te word.

- Holisties: Deur kommunikatiewe handelinge vind simboliese kommunikasie op alle vlakke plaas. Dit sluit die mens in die geheel in, met al die dimensies van die affektiewe, sosiale, emotiewe, konatiewe en estetiese wat betrek word. Dit dui ook op die geheelervaring van die kommunikasiegebeure waar die wêreld van die ervaarbare en dus ook die wêreld van die gespreksgenoot ter sprake kom. Die aktiewe moment van kommunikasie lê in die simboliseringsmoment waar tekens, kodes, strukture en handelinge betekenis buite hulleself verkry en wêrelde buite sigself betrek word.

Samevattend kan gesê word dat Christelike geloofskommunikasie 'n evangeliese spiritualiteit moet bevorder; identiteit moet skep; deursigtig moet wees (dus nie-instrumenteel, en nie met 'n eie agenda of subteks nie); vertroue moet bevorder; verhoudings moet bou; moet ophelder en nie vertroebel nie; sekuriteit moet gee in mense se lewens voor God; 'n liefdevolle ruimte moet skep waarbinne mense veilig voel; kommunikasie moet wees wat Christelike waardes, Bybelse beginsels en evangeliese optrede bevorder. 'n Praktyk van gelykwaardige en positiewe kommunikasie moet voortdurend nagestreef word.

\section{Die implementering van ' $n$ teologiese kommunikasieteorie in die handelingsveld van kerklike publikasies en visuele verkondiging \\ 'n Globale benadering met die oog op ' $n$ korporatiewe identiteit vir die kerk}

Deur sy betrokkenheid by die publikasies van die kerk het Wian Kloppers meer as twintig jaar gelede daarvoor begin pleit dat in die handelingsvelde van kerklike publikasies en visuele verkondiging ' $n$ positiewe kommunikasiepraktyk geskep moet word - dat trouens 'n globale kommunikasiepraktyk vir die kerk bedink moet word. In 'n omvattende studie argumenteer hy vanuit die perspektief van 'n teologiese kommunikasieteorie dat die kommunikatiewe handelinge ten opsigte van ál die handelingsvelde in die kerk vanuit ' $n$ holistiese benadering bedink moet word en dat ' $n$ eie sigbare korporatiewe identiteit, ' $\mathrm{n}$ eenheidsbeeld vir die kerk, bewustelik bevorder moet word:

Die kerk sal deur middel van alle kommunikasiemiddele, en veral deur middel van haar publikasies, 'n eie kerklike vorm van 'bemarking' (bekendstelling en planmatige bevordering) van ' $n$ eie beeld (korporatiewe identiteit), ' $n$ besondere boodskap en missie moet ontwikkel. Dit moet duidelik gestel word dat hier nie sprake is van enige vorm van 'sekulêre bemarking' soos van goedere of produkte op ' $n$ uitstal-basis nie, ook nie van kompetisie met ander 'mededingers' of ander denominasies nie, maar bloot ' $n$ beter georganiseerde, doelgerigte poging om maksimaal van die middele tot die kerk se beskikking gebruik te maak om die kerk duideliker en meer effektief te laat optree. Daar is groot werk voor ten opsigte van die Kerk se globale kommunikatiewe potensiaal en die ontwikkeling van ' $n$ holistiese en multidimensionele kommunikasiepraktyk waarin 'n eie korporatiewe identiteit bewustelik bevorder kan word.

(Kloppers, W.C. 1997:347-349)

Die kommunikasiepraktyk moet in die eerste plek daarop gerig wees om die beeld van die kerk in die oë van (veral jong) lidmate en buitestaanders positief te beïnvloed. In die kerk moet die maksimum kommunikasiemoontlikhede in terme van die kerk se boodskap en doelstellings bewerkstellig word. Trouens, deur dit nie te doen nie, word reeds ' $\mathrm{n}$ bepaalde identiteit van ongeërgdheid, onbetrokkenheid of selfs negatiwiteit gekommunikeer. Die kommunikasieproses moet na binne én na buite gerig wees en moet die kerk uit haar na binnegekeerdheid, op ' $n$ visie buite die grense van die kerk rig. Die fokus (visie) behoort nie net op binnekerklike worsteling om oorlewing gerig wees nie, maar moet die kerk só inspireer en van binne-uit sterk maak sodat die kerk met krag en oortuiging na buite (missionêr) kan optree. 
Gemeentes formuleer toenemend vir hulleself ' $\mathrm{n}$ visie en missie om daarvolgens vir hul eie lewe en bediening jaarliks doelwitte te formuleer en aan die hand daarvan sinvol en doelgerig te werk en te lewe. Het dit nie tyd geword dat die 'kerkleiding' ook op soortgelyke wyse die kerk lei aan die hand van 'n behoorlik geformuleerde visie- en missiestelling, en met jaarlikse doelwitte aan die kerk as geheel koers probeer gee nie? Hierdeur kan 'n nuwe soort gesprek tussen die 'kerkleiding' en gemeentes op dreef kom en kan simmetriese dialoog ook op hierdie vlak bevorder word. 'n Groter bewustheid van die waarde van oop en vrye kommunikasie behoort 'n wesenlike deel van 'n kerk te wees wat daarop gesteld is dat daar nie ' $n$ hiërargie in die kerk geld nie en dat almal deur Christus alleen regeer word. Christus se kommunikasie, die uitleef van die liefde, behoort in só 'n kerk sigbaar te word.

(Kloppers, W.C. 1997:350-353)

\section{'n Praxis van oop en simmetriese kommunikasie met die oog op vertroue}

Vanuit die teologiese kommunikasieteorie, behoort bestaande kommunikasiepraktyke in die kerk uitgebou te word tot ' $n$ dinamiese kommunikatiewe praxis waar nuwe kommunikatiewe handelingspatrone in spel gebring word ter verbetering van die huidige praktyk (vgl. Van der Ven 1993 wat aantoon dat die begrip praxis dui op 'n dinamiese en voortgaande proses waardeur 'n bestaande praktyk voortdurend tot nuwe praktyk verruim word). Die teologiese teorie van kommunikatiewe handelinge bied ' $n$ uitdaging vir die kerk veral ten opsigte van 'n ander styl van kommunikasie wat gerig is op die volle mens en nie slegs op die intellek nie, maar waar ook die belewenisse, gevoelens en verwagtings van lidmate betrek word. Volgens Heitink word hoë eise aan dié wyse van geloofskommunikasie gestel: 'wederkerigheid, openheid en waarachtigheid mogen hier als voorwaarden gelden. In de sfeer van kerk en geloof dient het communicatief handelen het strategisch handelen te doordringen' (Heitink 1993:165).

Voortspruitend hieruit word die pleidooi gerig dat die terminologie vir kommunikasie ook aan die vereistes van 'n teologiese kommunikasieteorie moet voldoen. In sy studiestuk oor 'n kommunikasiepraktyk vir die Nederduitsch Hervormde Kerk, wys Kloppers daarop dat terme soos kommunikasiestrategie en kommunikasiebeleid vermy behoort te word ten gunste van die term kommunikasiepraktyk (vgl. Kloppers 2004). Hy wys op Habermas se argument dat wanneer die vlak van kommunikatiewe handeling verlaat word, oorgegaan word tot strategiese handeling waarvolgens gepoog word om met magsmiddele invloed uit te oefen (Habermas 1982 II:40-45) en argumenteer verder dat in die woord 'strategie' reeds ' $n$ negatiewe klank opgesluit is - dié van die instrumentele beheersing van mense. Die kerk se denke rondom identiteit mag nie bepaal word deur strategieë of raamwerke waarbinne almal volgens ' $n$ bepaalde patroon moet funksioneer nie. Kommunikasie is per definisie ook dinamies en oop en behoort daarom in wese nie strategies bepaal te word nie - te meer wanneer dit as geloofskommunikasie onder die leiding van die Heilige Gees, deur inspirasie bepaal, deur spirituele kreatiwiteit gedring, en deur individuele gelowiges met unieke talente en gawes, beoefen word.
Alle kerklike kommunikasie moet op simmetriese kommunikasie in 'n liefdevolle ruimte ingestel wees. Dit beteken dat die boodskap nie in ' $n$ drukgang van eenrigtingverkeer na 'n ontvanger 'versend word', asof die 'ontvangs' daarvan eintlik irrelevant is nie. Dit neem die ontvanger volledig in ag as subjek, as 'n medekommunikator wat deelneem aan die gesprek. Waar kommunikasie misluk, behoort kommunikasie wat gerig is op beter wedersydse verstaan, opnuut te begin. Indien hierdie nuwe gesprek nie ook plaasvind nie, soos dikwels in ons kerklike praktyk gebeur, bou frustrasie op, veral by dié wat normaalweg aan die 'ontvangkant' van sodanige kommunikasiegebeure staan. Dit lei tot vervreemding en wantroue wat sneeubal tot gebrekkige verhoudinge. Dit gebeur veral in situasies van gesprekvoering waar mense hulleself in meerdere posisies ag omdat hulle meen hulle het meer kennis of meer status as die gespreksgenote. Die nadelige uitwerking op die kerk se werk spreek vanself.

Kommunikasie moet sonder bybedoelings of verskuilde agendas wees. Egte en geloofwaardige kommunikasie moet nagestreef word. Die dubbele impak van verbaleén nieverbale kommunikasie, die parateks, bepaal die kommunikatiewe trefkrag en geloofwaardigheid van die kerk. Die volle impak van nieverbale en visuele kommunikasie behoort dus altyd grondig aandag te kry. Die styl van kerklike media, tydskrifte, briewe, briefhoofde, 'n kerkgebou, 'n gemeentekantoor, 'n kerkkantoor se atmosfeer - alles behoort toeganklikheid, egtheid, Christelike liefde, hoop en vertroue uit te straal.

\section{'n Praxis van outentieke geloofskommunikasie in die handelingsveld van visuele verkondiging}

Die lewende en beeldryke Woord van God bied die potensiaal om met God self in gesprek te tree en God te ontmoet. Die menswording van Christus, die sigbaarwording van die Woord, dui teologies daarop dat'n veel wyer veld van kommunikasieen verkondigingsmoontlikhede bestaan as slegs die gesproke of gepredikte woord. Verkondiging geskied ook deur middel van sigbare en simboliese middele in kerkpublikasies, kuns en ander vorme van visuele kommunikasie. Die kragtige eienskappe en inherente vermoëns wat geloof en die visuele met mekaar in gemeen het, maak dit moontlik dat kerklike literatuur, kommunikasiemedia en visuele verkondiging in verskillende vorms as ' $n$ hegte eenheid binne betekenisvolle kommunikasieverhoudings kan funksioneer (vgl. Kloppers 2003a).

Kloppers het ' $n$ bepaalde handelingsveld teologies in fokus gebring, naamlik visuele verkondiging of visuele kommunikasie sodat daarmee die oog geopen kon word vir die verskeidenheid van moontlikhede op alle terreine binne die kerk. Navorsingsvelde wat hy geïdentifiseer het vir verdere ondersoek, en waaraan voortdurend in die teologiese diskussie sowel as in die opleiding van predikante aandag gegee behoort te word, is die volgende:

- visuele verkondiging in die breë;

- verkondiging deur middel van kuns, simbole, argitektuur, e.d.m.;

- liggaamstaal as visuele verkondiging;

- stilte as kommunikatiewe simbool/metafoor in die erediens;

- die parateks van kerkpublikasies (ook die Bybel); 
- die gesprek tussen die teologie en kuns;

- die beeldende en verbeeldende aspekte van geloof;

- eietydse beeld- en simboolvorming vir die kerk;

- interpersoonlike kommunikasie;

- 'n lewensbeskoulike mediagesprek t.o.v. kerklike kommunikasie;

- die visuele uitbou van die korporatiewe identiteit van die kerk as liggaam van Christus.

(Kloppers, W.C. 1997:370)

In die proses van deelnemende betrokkenheid het hy egter ook konkreet by projekte op 'n wye vlak betrokke geraak, om dit wat hy teoreties beredeneer het, in die praktyk te beoefen en daarmee ' $n$ verruimde praxis te bewerk. So skep hy ' $n$ korporatiewe identiteit vir die Nederduitsch Hervormde Kerk wat in ' $\mathrm{n}$ veelheid van kommunikasiemedia, soos briefhoofde, e-pos en die webblad neerslag kry. Vroeër reeds het hy vir die Nederduitsch Hervormde Sustersvereniging (NHSV) 'n korporatiewe identiteit ontwerp met 'n logo, briefhoofde en glansbrosjure vir bemarking, wat by die 41ste Kongres van die NHSV in 1996 bekend gestel is (vgl. die beriggewing in Konteks en die Christelike Vrou, Julie 1996). Benewens die werk om die identiteit van instansies, komitees en vergaderings in die kerk uit te beeld, poog hy om hierdie liggame deur die visuele met mekaar in verband te bring en so met mekaar te laat 'praat'. Hy was en is betrokke by die grafiese ontwerp en versorging van verskeie publikasies soos Almanak en Bybelse Dagboek, Kerkorde, Diensboek, Gesinsaam, Dagboek vir Christenvroue, stukke vir die Algemene Kerkvergadering, kongresstukke van die NHSV, die nuwe jaarlikse kalender, die plakkaat met die visuele uitbeelding van die kerkjaar, buiteblaaie vir boeke, briefhoofde, kategeseboeke, en dies meer. Verder is hy ook verantwoordelik vir toerusting rakende visuele en simboliese kommunikasie in elke vorm wat kan meewerk om die beeld en boodskap betekenisgewend en sinvol 'uit te beeld' of 'in te prent'.

Toenemende aandrang van verskillende instansies binne die kerk vir projekte van hierdie aard illustreer die behoefte wat op verskillende vlakke en binne elke werksterrein van die kerk ontwikkel het en wat uitgebou behoort te word. Elke vorm van kommunikasie, verbaal en nieverbaal, behoort gebruik te word om die kerk se beeld en identiteit uit te bou en in die wêreld te bevorder. In die geheelprentjie is elke stuk kommunikasie nie maar net toevallig nie, maar deel van die boodskap wat die wêreld moet oortuig dat Christus in ons lewe is en ons in Hom. Alle kommunikasie moet daartoe bydra dat die kerk as liggaam van Christus, as die stem en beeld van God in die wêreld, gehoor en gesien word.

\section{Die implementering van ' $n$ teologiese kommunikasieteorie in die handelingsveld van die erediens en die kerklied}

\section{Die kerklied as kommunikatiewe handeling: Heersersvrye kommunikasie gerig op deelname}

Een van die belangrikste teologiese vereistes vir kommunikatiewe handelinge in diens van die evangelie is dat dit heersersvry en gelykwaardige moet wees. Dit moet ooreenstem met die gees van liefde van Jesus Christus, naamlik toegeneë en uitnodigende optrede, optrede gerig op deelname. Ruimte vir die kerklied vereis nie net hierdie situasie nie, maar die kerklied kan ook by uitstek hierdie situasie skep. In die Kolossensebrief (Kol3:16) word die oproep gemaak dat die gelowiges met dankbaarheid in hulle harte psalms, lofgesange en ander geestelike liedere tot eer van God moet sing. Kolossense 3:12-16 kan as 'n 'herrschaftsfreies Modell' vir die gemeentelewe beskryf word (Krummacher 1994:137). Die gelykwaardigheid van almal word in vers 16 beklemtoon deur die oproep om mekaar te leer en te onderrig. Die oproep tot sang dui nie op 'n verpligting nie, maar ' $n$ geleentheid: 'Als intensive Möglichkeit wechselseitiger und gemeinschaftlicher Kommunikation erlaubt es die Erfahrung einer Demokratie, in der jeder jedem etwas mitzuteilen hat und ernstgenommen wird, indem er am Ganzen partizipiert'(Krummacher 1994:137).

Elkeen het iets om mee te deel. Elkeen word ernstig geneem. Elkeen neem deel aan die gebeure: die lof en dank aan God. Die sang is vervulling én skepping van 'n heersersvrye kommunikasiesituasie - 'n situasie waar die gelowiges, deur die verbondenheid aan die liggaam van Christus, uitgenooi word tot wedersydse deelname aan kommunikatiewe handelinge. Deur die sang kan deelname en medevoltrekking bewerkstellig word en kan gelowiges hulle ervarings en verwagtings handelend en singewend tot gestalte bring. Deur die sang kom die gelowiges met hul klag, hul protes, hul rou, maar ook met hul vreugde, hul geluk, hul dank, hul lof, hul bevryding.

Deur omgang met poëtiese tekste, beelde en musiek, kan 'spreekruimte' geopen word, ruimte vir die outentieke 'tot spreke kom' van die Woord van God en kan aan teologiese begrippe en ervarings nuwe gestalte en ekspressiwiteit verleen word. Musiek kan bydra tot 'n outentieke en geloofwaardige taal vir die geloof - om dít te artikuleer wat alle formulering te bowe gaan. Sang verbind die gelowiges onderling, maak hulle deel van die geloofsgemeenskap, laat hulle deelneem. Die doel van simboolkommunikasie is dan ook om deelname te bewerkstellig (vgl. Dingemans 1991:152 hierbo). Die heersersvrye kommunikatiewe handeling kry gestalte daarin dat elke gelowige se gawes in diens van die geheel van die liggaam van Christus gestel word.

\section{'n Praxis van kreatiewe geloofskommunikasie in die handelingsveld van die erediens}

Die erediens wil mense tot 'kreatiewe waarneming' van die werklikheid uitnooi en bemagtig (Heimbrock 1993:142). In die kommunikatiewe handelinge in die erediens word gereflekteer op en deur simbole - taalsimbole, visuele simbole, musiek, metafore, mites, rituele, ensovoorts. Dit is die draers van die getuienis wat geloof wek en versterk. Toenemend pleit teoloë vir die herwinning van die kunsgestalte van die erediens, vir die benutting van alle kunsvorme, asook die (kuns)vermoëns of gawes van alle lidmate, sodat 
die evangelie in die volle omvang sinvol en singewend verkondig kan word. 'Simbooltaal' is by uitstek geskik vir die spreke oor God, wat anders is as die bloot feitelike spreke. Simbooltaal het ' $n$ affektiewe uitdrukkingsvermoë wat deur rasionele argumentvoering nie bereik kan word nie. Vanweë die vermoë tot 'simbooltaal' vervul musiek in die erediens ' $n$ wesenlike funksie as kommunikatiewe handeling. Volgens Josuttis (1991) is musiek dus méér as vryetydsbesteding of 'blote' kunsgenot: 'Im Akt des Singens findet Vereinigung statt, Integration innerhalb des singenden Menschen, Kommunikation mit anderen bei Arbeit und Spiel, Initiation in das symbolische Universum der jeweiligen Gesellschaft' (Josuttis 1991:178, [outeur se eie kursivering]). Deur die sang as simboliseringsmoment, word groter werklikheidsgebiede betrek en beteken. As kommunikatiewe handeling, het sang ' $n$ estetiese en simboliese, ' $n$ bemiddelende funksie (vgl. Kloppers 2003c:137-139).

Bastian (1991:349) bepleit 'n Zusammenschau van religieuse kommunikasievorme. Hy pleit dat argitektuur en liturgie, prediking en Bybel, beeld en musiek as mediale kontekste verstaan, en weergegee word in die samewerking van alle elemente in die Gesamtkunstwerk van die Christelike erediens. Hy beklemtoon dat die God van die Bybel nie net na die ore nie, maar ook na die oё, die voet en die hand vra. So kan die vergete Doppelverkündigung (Bastian 1991:351) van woord en beeld weer na vore kom.

Kuns en musiek kom dáár ter sprake (tot spreke) waar geloof ter sprake (tot spreke) kom. Dit is 'n spreekvorm van die geloof. In die Liedboek van die Kerk (2001) is ' $n$ groot verskeidenheid nuwe lied- en liturgiese vorme opgeneem wat die geleentheid bied tot ' $n$ meer kreatiewe inrigting van die erediens tot 'n Gesamtkunstwerk. Moontlikhede vir meerdere deelname en betrokkenheid word ook gebied wat tot dusver onbekend in die Afrikaanse reformatoriese kerke was. Benewens nuwe vorme, soos kanons, akklamasies en response, is daar ook die moontlikheid vir 'n verskeidenheid voorsangers in afwisseling met die gemeente. Hierdeur word die geleentheid gebied dat lidmate op nuwe wyses betrokke kan wees by die sang.

Gelykwaardige optrede en die belang van elke mens, word beklemtoon deur die nuwe fokus op deelname en die priesterskap van alle gelowiges in die erediens. Soos die Liedboek, bied die Diensboek (2008) ook nuwe geleentheid tot die kreatiewe deelname van lidmate in ' $n$ balans tussen tradisie en vryheid. Die simboliese inkleding van die kerkjaar (Kloppers 2003b) het ook nuwe moontlikhede ontsluit vir visuele verkondiging in ' $\mathrm{n}$ Doppelverkündigung met die liedere vir'n bepaalde tyd in die kerkjaar. Die onlosmaaklike verband tussen die kerkjaar, die kerklied, visuele kommunikasie en simboliek as media vir geloofskommunikasie kan nie genoeg beklemtoon word nie.

\section{Samevatting en dankwoord}

Vanuit ons terreine en werksaamhede is nuwe moontlikhede in die kerk ontsluit deur die Liedboek van die Kerk (2001), 'n verruimde 'kommunikasiepraktyk' vir die kerk, 'n nuwe
Diensboek (2008), 'n korporatiewe identiteit vir die kerk, en ' $n$ bewussyn vir die kerkjaar wat gevestig en uitgebou is. Die meeste hiervan is deurgevoer in die tydperke van professor Theuns Dreyer se voorsitterskap van die Kommissie van die Algemene Kerkvergadering. As 'n leiersfiguur wat gepoog het om die teologiese beginsels vir kommunikatiewe handelinge uit te leef, en dus ingestel was op gelyke, oop en egte kommunikasie, het hy ook die ruimte gebied tot meerdere deelname en 'n plek vir mense se gawes binne die kerk. Mag hy die wete hê dat deur sy optrede die kerk meer na die beeld van Christus gevorm is, om so ook sigbaar in die wêreld as liggaam van Christus op te tree en te dien.

\section{Erkenning Mededingende belange}

Die outeur verklaar dat sy geen finansiële of persoonlike verbintenis het met enige party wat haar nadelig kon beïnvloed in die skryf van hierdie artikel.

\section{Literatuurverwysings}

Arens, E. (Hrsg.), 1994, Gottesrede - Glaubenspraxis: Perspektiven theologischer Handlungstheorie, Wissenschaftliche Buchgesellschaft, Darmstadt.

Bäumler, C., 1984, Kommunikative Gemeindepraxis: Eine Untersuchung ihrer Bedingungen und Möglichkeiten, Kaiser, München.

Bastian, H., 1991, 'Auge und Ohr, Sehen und Hören: Eine Revision theologischer Mediendidaktik', in D. Zilleßen (Hrsg.), Praktisch-theologische Hermeneutik, Ansätze - Anregungen - Aufgaben, pp. 339-352, CMZ Verlag, RheinbachMerzbach.

Dingemans, G.D.J., 1991, Als hoorder onder de hoorders: Hermeneutische homilitiek, Kok, Kampen.

Habermas, J., 1982, Theorie des kommunikativen Handelns I \& II, Suhrkamp, Frankfurt.

Habermas, J., 1984, The theory of communicative action: Reason and rationalization of society, vol. 1, transl. T. McCarthy, Beacon, Boston, MA.

Heimbrock, H., 1993, Gottesdienst: Spielraum des Lebens, Deutscher Studien Verlag, Weinheim

Heitink, G., 1993, Praktische Theologie: geschiedenis, theorie, handelingsvelden, Kok, Kampen.

Hoffman, L.A., 1988, The art of public prayer: Not for clergy only, Pastoral Press, Washington.

Josuttis, M., 1991, Der Weg in das Leben: Eine Einführung in den Gottesdienst auf verhaltenswissenschaftlicher Grundlage, Kaiser, München.

Kloppers E.C., 1997, 'Liturgiese musiek as kommunikatiewe handeling in ' postmoderne era', DTh-proefskrif, Departement Praktiese Teologie, Universiteit van Suid-Afrika, Pretoria.

Kloppers, E.C., 2009, 'n Skerp bewussyn vir die Kerkjaar - 'n Lewenswyse', Konteks, November, n.p.

Kloppers, W.C., 1997, 'Die kommunikatiewe vermoë van die parateks van kerkpublikasies', DTh-proefskrif, Departement Praktiese Teologie, Universiteit van Suid-Afrika, Pretoria.

Kloppers, W.C., 2003a, 'Wanneer die beelde uit die oog geneem word... Teks en beeld: ' $\mathrm{n}$ Teologiese probleem', HTS Teologiese Studies/Theological Studies 59(1), 85-97.

Kloppers, W.C., 2003b, 'Die Kerkjaar en liturgiese kleure', Vir die Musiekleier 30, Desember, 23-28.

Kloppers, E.C., 2003c, 'Singend is die geloof in sy element ... Gemeentesang as kommunikatiewe handeling', Acta Theologica 23(2), 136-145.

Kloppers, W.C., 2004, 'Kommunikasiepraktyk in die Ned Hervormde Kerk van Afrika', in Agenda 67ste Algemene Kerkvergadering, pp. 163-170, n.p.

Krummacher, C., 1994, Musik als praxis pietatis: zum Selbstverständnis evangelischer Kirchenmusiek, Vandenhoeck, Göttingen.

Liedboek van die Kerk, 2001, NG Kerk-Uitgewers, Kaapstad.

Nederduitsch Hervormde Kerk van Afrika, 2008, Diensboek, Sentik, Pretoria.

Søgaard, V., 1993, Media in church and mission: Communicating the Gospel, William Carey, Pasadena, CA.

Van der Ven, J., 1993, Ecclesiologie in context, Kok, Kampen.

Zerfaß, R., 1994, 'Gottesdienstliches Handeln', in E. Arens (Hrsg.), Gottesrede Glaubenspraxis: Perspektiven theologischer Handlungstheorie, pp. 110-130, Wissenschaftliche Buchgesellschaft, Darmstadt.

Zilleßen, D. (Hrsg.) 1991, Praktisch-theologische Hermeneutik, Ansätze - Anregungen - Aufgaben, CMZ Verlag, Rheinbach-Merzbach. 